Article

\title{
Ten Year Evaluation of Carbon Stock in Mangrove Plantation Reforested from an Abandoned Shrimp Pond
}

\author{
Naohiro Matsui $^{1 \text {,*, Keiyo Morimune }}{ }^{2}$, Wijarn Meepol ${ }^{3}$ and Jirasak Chukwamdee ${ }^{4}$ \\ 1 Department of Environment, Kanso Technos Co., Ltd., Osaka 541-0052, Japan \\ 2 Power Engineering R\&D Center, The Kansai Electric Power Co., Inc., Kyoto 609-0237, Japan; \\ E-Mail: morimune.keiyo@b5.kepco.co.jp
}

3 Ranong Mangrove Forest Research Center, Department of Marine and Coastal Resources, Tambon Ngao, Muang District, Ranong 85000, Thailand; E-Mail: wijarn_m@hotmail.com

4 Department of National Park, Wildlife and Plant Conservation, 61 Pholyothin Road, Ladyao, Chatuchak, Bangkok 10900, Thailand; E-Mail: j_chukwamdee@hotmail.com

* Author to whom correspondence should be addressed; E-Mail: matui_naohiro@kanso.co.jp; Tel.: +81-66-263-7378; Fax: +81-66-263-7309.

Received: 2 April 2012; in revised form: 21 May 2012 / Accepted: 12 June 2012 /

Published: 20 June 2012

\begin{abstract}
Forest carbon stocks - both in terms of the standing biomass and the soil organic carbon (OC) - were monitored in the mangrove plantation reforested from an abandoned shrimp pond for the 10 years following land excavation. Excavation to a level of $25 \mathrm{~cm}$ below the existing ground level increased the inundation time of tidal water from 463 to 7,597 hours per year, resulting in a significant increase of survival/growth rates for planted mangrove species, Rhizophora mucronata (RM) and Bruguiera cylindrica (BC), and of carbon stocks as well. RM showed high rates of standing biomass accumulation with 98.7 ton/ha while 28.8 ton/ha for BC was measured over 10 years in the excavated area. In contrast, the unexcavated area showed low rates of biomass accumulation, 1.04 ton/ha for $\mathrm{RM}$ and 0.53 ton/ha for $\mathrm{BC}$ in the same period. The excavated area recorded a twofold increase of soil OC in the upper $5 \mathrm{~cm}$ of the surface soil from 71.8 to 154.8 ton/ha in 10 years, however it decreased to 68.3 ton/ha in the unexcavated area where soil OC is susceptible to decomposition. These results imply that the potential of carbon sinks in reforested land from abandoned areas cannot be developed unless hydraulic conditions are properly recovered. The fast growing species Avicennia marina (AM) grew quickly for the first two years after colonization but its growth slowed down afterwards, showing a limited ability of carbon capture.
\end{abstract}


Keywords: mangrove reforestation; excavation; soil OC; standing biomass; blue carbon

\section{Introduction}

The vegetated coastal habitats, including mangroves, provide a large carbon sink capacity [1]. These areas are responsible for $50-71 \%$ of the organic carbon in ocean sediments which is sequestered from atmospheric carbon [2]. Atmospheric carbon captured by coastal ecosystems is presently called 'Blue Carbon' and it has recently been the focus of reports by the United Nations Environment Programme (UNEP) and the International Union for the Conservation of Nature (IUCN). The high carbon sequestration potential of coastal ecosystems and the growing interest for exploring its potential in existing and emerging climate change frameworks, have been intensively argued [3-7].

Signatory countries of the United Nations Climate Change Framework (UNFCCC) are obligated to submit annual National Inventory Submissions (NIS) to record the country's greenhouse gas emissions from anthropogenic activity, as well as sequestration from land use and forestry [8]. The section of Land Use, Land-Use Change and Forestry (LULUCF) in NIS, accounts for the carbon budget on the terrestrial ecosystem management including forests. However, this section solely includes the carbon budget relating to direct human management of ecosystems. Blue Carbon ecosystems, whether managed or not, are not accounted for under LULUCF and thus, not included in the UNFCCC.

In order for Blue Carbon ecosystems to be accounted for in the LULUCF process, an important step would be to accumulate knowledge regarding the fate of blue carbon associated with land-use change and with vegetation recovery. There is still considerable uncertainty regarding these estimates, therefore multi-year measurements are necessary to improve our understanding, especially to determine human disturbance to carbon (C) storage, to assess the amount of $\mathrm{C}$ entering long-term storage.

Blue Carbon sinks are lost at a rate of $0.7-7 \%$ annually; four times faster than the rate of rainforest loss [9-13]. Several decades of coastal exploitation, such as shrimp pond construction, led to a significant amount of soil carbon loss [14,15]. In Thailand, 200,000 ha of mangrove forests were destroyed between 1961 and 1996 [16], being mainly converted to shrimp ponds. As a consequence, large areas of abandoned shrimp ponds currently remain in an unproductive condition. This extraordinary abandonment is attributed to the fact that the majority of shrimp farms in Thailand are abandoned after five years because of drastic declines in yields resulting from shrimp viral disease [17].

There have been several attempts to restore abandoned aquaculture ponds back to mangroves. Rehabilitation of mangroves through restoring a natural hydrology was emphasized by Lewis $[18,19]$. Moreover, successful restorations of mangroves were achieved through restored hydrology alone [20], by hydrologic reconnection to the river [21] and by reopening obstructing banks [22].

However, these antecedent studies did not fully examine the effectiveness of hydraulic restoration for enhancement of $\mathrm{C}$ stocks. Understanding carbon changes due to these treatments is important in terms of carbon management against global warming.

Given the above, this study has the following objectives: (1) to examine the effectiveness of land preparation, excavation in this case, in stimulating mangrove growth; (2) to assess changes of carbon stocks associated with land preparation. 


\section{Experimental Section}

\subsection{Study Site}

The study was conducted at an abandoned shrimp pond located at Khanom, Nakorn Sri Thammarat province, Thailand $\left(9^{\circ} 17^{\prime} \mathrm{N}, 9^{\circ} 49^{\prime} \mathrm{E}\right.$ ) (Figure 1). According to the local people, the study area had been a mangrove plantation before the land was converted to a shrimp pond. After abandonment in the 1980s, sedimentation formed within the pond. Since a number of active shrimp ponds are still operating in the surrounding area (Figure 2), effluents from these ponds flowed via creeks to deposit in the study site. On the eastern coast of the southern Thai Peninsula, $18.5 \mathrm{~km}^{2}$ of the coastal areas altered significantly between 1975 and 2006, with $17.3 \mathrm{~km}^{2}$ of erosion and $1.2 \mathrm{~km}^{2}$ of accretion. [23]. Besides the effluents from the surrounding active shrimp ponds, the study site is likely to receive sedimentation from offshore. Before land treatment, the area was covered with Suaeda maritima and Sesuvium portulacastrum (Figure 3), which are indicators of dry and saline soil, and with the pioneer mangrove species Avicennia marina (AM).

Figure 1. Location of the study site: Khanom, Nakorn Sri Thammarat province, Thailand.

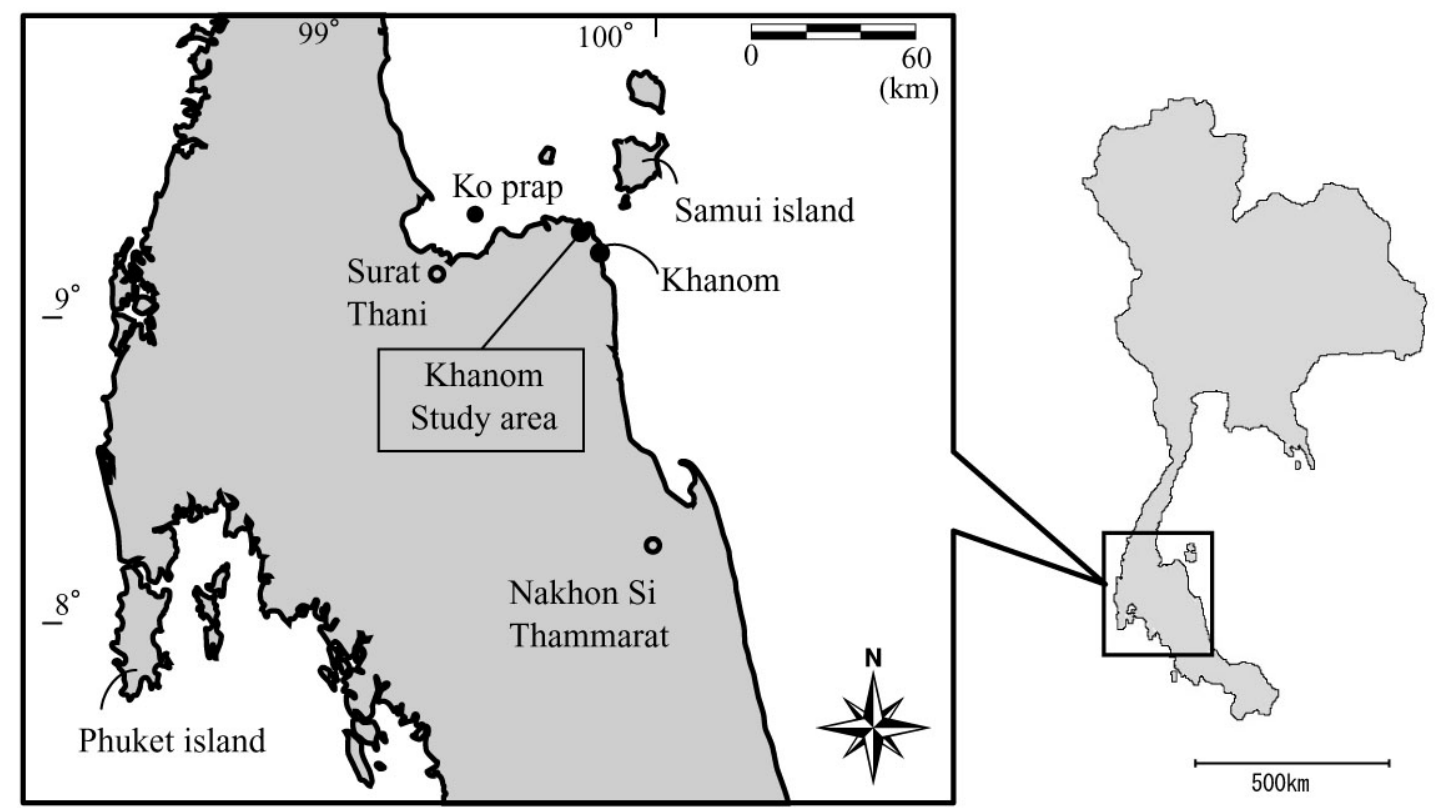


Figure 2. Aerial picture of the study site taken in September 2003. The area marked by the green rectangle shows the study site and that marked by red shows the excavated area. A number of shrimp ponds are located near the study site, some of which are still in operation.

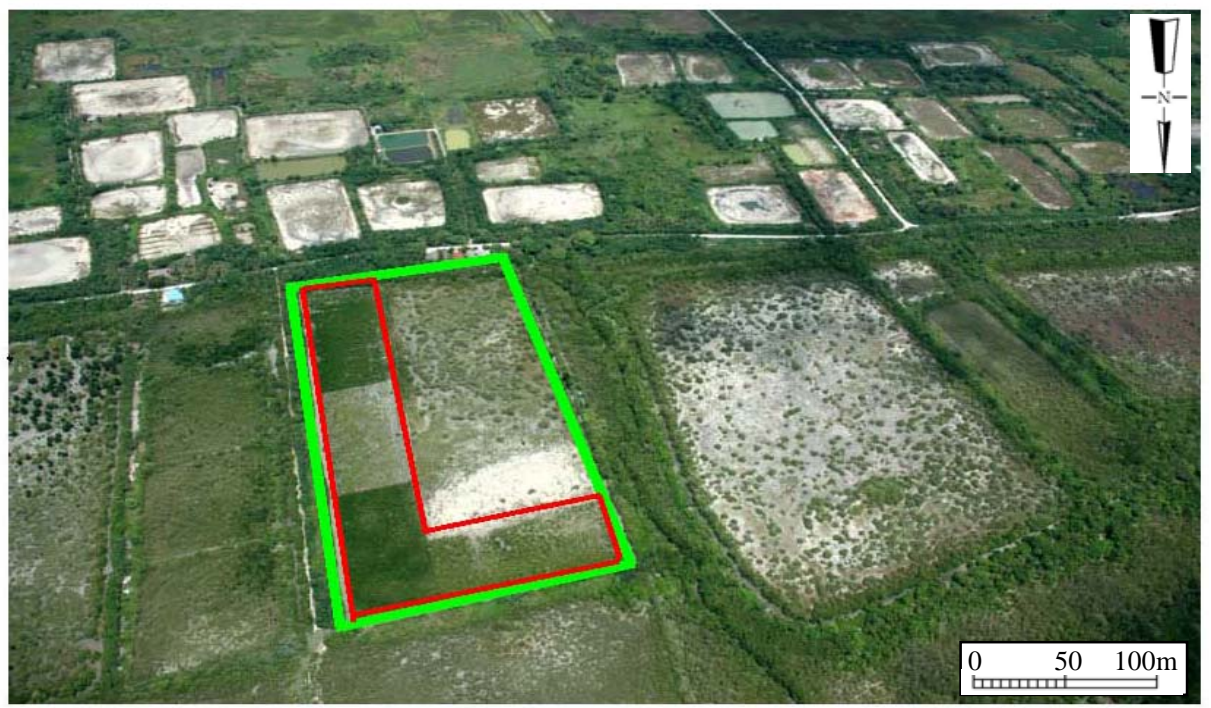

Figure 3. (a) Condition of the study site before the land treatment (August 2001). Note that the study site was fully covered by Suaeda maritime, which is a common halophyte in the region; (b) The study site immediately after mangrove planting (September 2001). In the foreground is the excavated area and in the background the unexcavated area, the difference of the ground level between the two areas is $25 \mathrm{~cm}$.

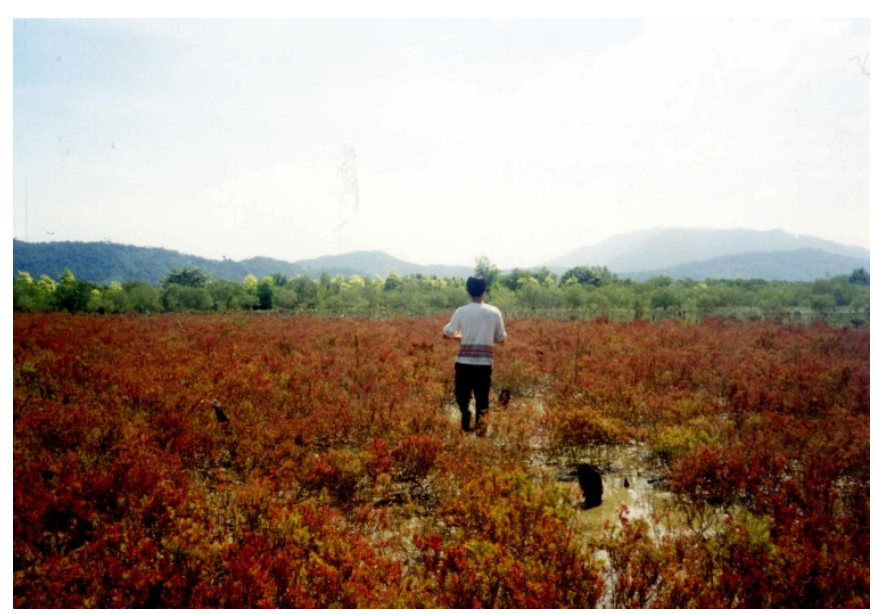

(a)

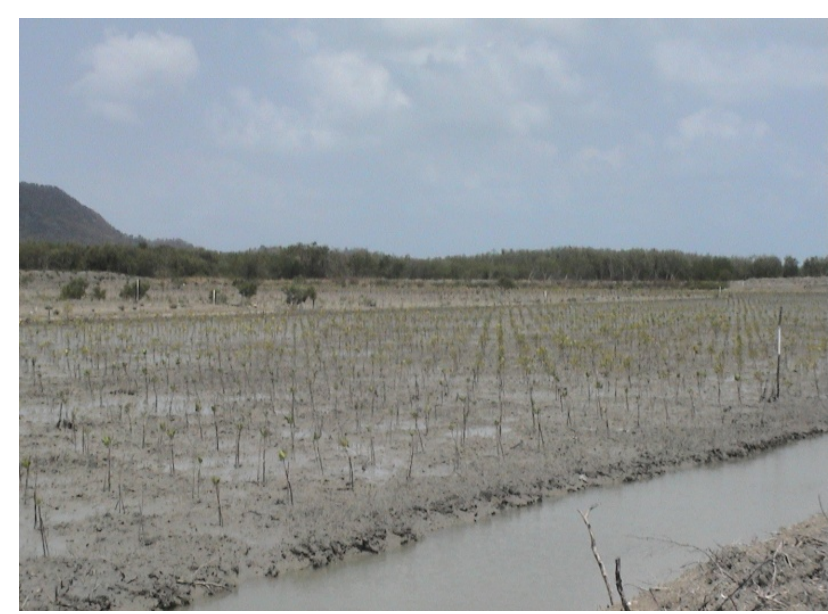

(b)

\subsection{Land Treatment}

The size of the study site is 4.5 ha, being $150 \mathrm{~m}$ wide and $300 \mathrm{~m}$ long (Figure 4). The elevated land was excavated using heavy machinery in August 2001, resulting in reducing the elevation by $25 \mathrm{~cm}$, which is $10 \mathrm{~cm}$ lower than the mean sea water level. This enabled the access of tidal water into the area, where water flow was previously prevented by the height of the elevated land. The increased frequency of water inundation brought by the excavation was expected to improve forestry 
productivity and land quality in the area. Half of the site was left unexcavated for a comparison with the excavated area. Ground level was measured using an auto-level (AFL 320; Pentax Industrial Instrument Co., Ltd., Tokyo, Japan) in December 2007. Water levels in the study site were recorded during the ground level measurement and inundation frequency was calculated by referring to the 2007 tidal records of the nearest tide recording station (Ko Prap, Surat Thani) to the study site (Figure 5).

Figure 4. Layout of the study site. The rectangular area within the double line indicates the unexcavated area. Rhizophora mucronata (RM) and Bruguiera cylindrica (BC) were planted in five blocks and four blocks, respectively.

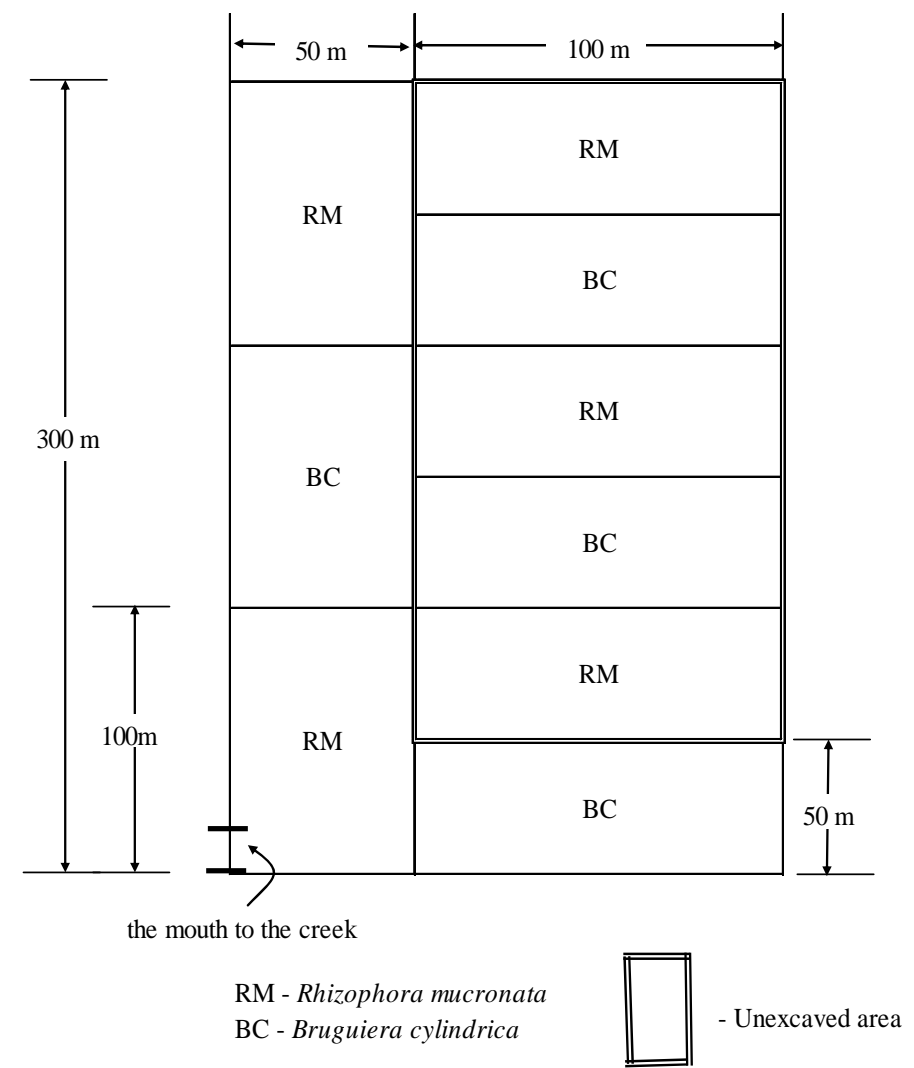

Figure 5. Water inundation duration (in hours) throughout 2007 in the unexcavated and the excavated area.

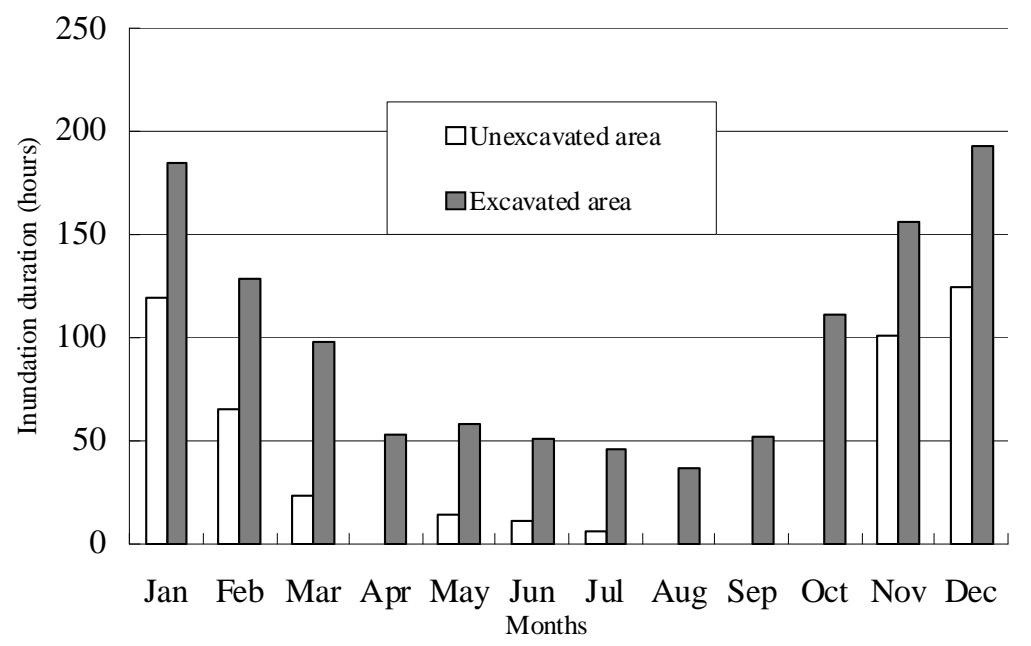




\subsection{Mangrove Planting}

We planted two mangrove species, Rhizophora mucronata (RM) and Bruguiera cylindrica (BC), in September 2001 at a spacing of $1.5 \times 1.5 \mathrm{~m}$, which is the standard spacing designated by the Thai government. RM is the species that local people prefer to plant, while $\mathrm{BC}$ is the species that grows naturally in areas adjacent to the study site. Seedlings with an average height of $50 \mathrm{~cm}$ for RM and $20 \mathrm{~cm}$ for $\mathrm{BC}$ were prepared for a half year prior to replanting at the nursery belonging to the Department of Marine and Coastal Resources located in Khanom.

RM was planted in five different blocks and BC in four blocks (Figure 4). Total plantation area for RM and BC were 2.5 and 2.0 ha, respectively. The number of RM planted was 4,488 for the excavated area and 6,732 for the unexcavated area while 4,488 BC seedlings were planted on each of the excavated area and unexcavated area. In total, 20,196 trees were planted during the course of the study.

\subsection{Tree Growth and Standing Biomass Measurements}

After the mangroves were planted in September 2001, the tree height and survival rate were measured for approximately $17.6 \%$ of all planted trees on six occasions: February 2002, March 2003, November 2003, November 2004, October 2005 and August 2011, representing intervals from the planting of approximately $0.4,1.5,2.3,3.3,4.2$ and 10 years, respectively. Since survival rate of planted trees is affected by various factors such as land treatment (excavation in this case), and species, key-factor/key-stage analysis was performed by MANOVA test (JMP 4.0, SAS Institute Inc.) in order to identify which stage and factor contributed most to the survival rate [24].

The diameter at breast height $(\mathrm{DBH})$ was measured during the measurement period on two occasions (in October 2005 and in August 2011) to calculate the standing biomass of the planted mangroves. The biomass of RM was calculated using the equation developed by Meepol [25] while the biomasses of BC and AM were determined using the equation proposed by Pranchai [26]. These equations were originally proposed for the region where this study site is located. Thereby it was thought most appropriate to use them for the biomass calculation in this study.

\subsection{Soil Sampling and Analysis}

Prior to land treatment, soil C content was measured from surface soils collected at three different places. To assess changes in soil $\mathrm{C}$ after the excavation, soils were sampled/analyzed from around 10 points of both the excavated area and the unexcavated area on four occasions: two occasions before excavation (August 2001) and at 2.3 years after excavation (July 2003) from bulk samples and another two occasions 4.1 years after planting (September 2005) and at 10 years after planting (August 2011) from soil core samples. Soil core samples were randomly collected from surface soils (0-5 cm) with 100 cc volumetric cylinders (DIK-5561; Daiki Rika Kogyo Co., Ltd., Kounosu, Japan). Total C was determined using the dry combustion method (NC-analyzer 1000; Sumigraph, Shimadzu Co., Ltd., Kyoto, Japan). Soil organic carbon (OC) was estimated using bulk density calculated from drying core samples.

Statistical analysis was carried out for total C using Tukey's test (JMP 4.0, SAS Institute Inc., Cary, NC, USA) and differences at the $p<0.05$ level were considered to be significant. 


\section{Results and Discussion}

\subsection{Survival Rate and Tree Growth}

In general, survival rates remained largely invariant within the excavated area during the measurement period; however, the survival rate of BC was remarkably lower in the unexcavated area even from the early measurements (Figure 6). The survival rate of RM in the excavated area decreased slightly one year after planting (March 2003), but became constant thereafter. Survival rates of RM in the unexcavated area decreased gradually and dropped to 33\% at the 10th year after planting (August 2011).

Key-factor/key-stage analysis showed that 4.2 years after planting (November 2004) was the most determinant stage for survival of the planted trees (Table 1). Land treatment (excavation in this study) influenced the survival rates as strongly as species, though a third contribution to the survival rate is still unknown. This result suggests that when planting mangroves in an abandoned area, attention should be paid not only to species selection but also to the treatment of land in order to attain favorable survival rates. Tree growth was highest for RM in the excavated area (Figure 7) with tree heights exceeding $500 \mathrm{~cm}$ after 10 years (August 2011). Although RM tree growth resembled that of BC in the early stages, significant differences were recorded by 4.2 years after planting (November 2004). In the unexcavated area, RM showed only slight tree growth and BC also grew slightly more with just over $100 \mathrm{~cm}$ growth in 10 years.

Table 1. Key-factor/key-stage analysis for the survival rates of the planted mangrove species.

\begin{tabular}{cccccccc}
\hline \multirow{2}{*}{$\begin{array}{c}\text { Species and } \\
\text { treatments }\end{array}$} & $\begin{array}{c}\mathbf{2 0 0 2} \\
\text { February }\end{array}$ & $\begin{array}{c}\mathbf{2 0 0 5} \\
\text { October }\end{array}$ & $\begin{array}{c}\mathbf{2 0 0 3} \\
\text { November }\end{array}$ & $\begin{array}{c}\mathbf{2 0 0 4} \\
\text { November }\end{array}$ & $\begin{array}{c}\mathbf{2 0 0 5} \\
\text { October }\end{array}$ & $\begin{array}{c}\mathbf{2 0 1 1} \\
\text { August }\end{array}$ & Total $^{1}$ \\
\hline Spp. & 12.1 & 128.9 & 179.4 & 668.3 & 209.5 & 329.0 & $1,198.2$ \\
Excavation & 9.2 & 120.7 & 167.2 & 629.3 & 187.7 & 264.4 & $1,114.0$ \\
Error & 9.5 & 115.5 & 160.4 & 613.2 & 178.8 & 255.9 & $1,077.3$ \\
Total $^{2}$ & 30.7 & 365.0 & 507.0 & $1,910.7$ & 576.0 & 849.3 & $3,389.5$ \\
\hline
\end{tabular}

Note: All values are multiplied by $10^{2}$ to facilitate the comparison; ${ }^{1}$ this column shows which factor is the key factor; ${ }^{2}$ this row shows the key stage.

Figure 6. The survival rate of Rhizophora mucronata (RM) and Bruguiera cylindrica (BC) from 5 months to 10 years after planting.

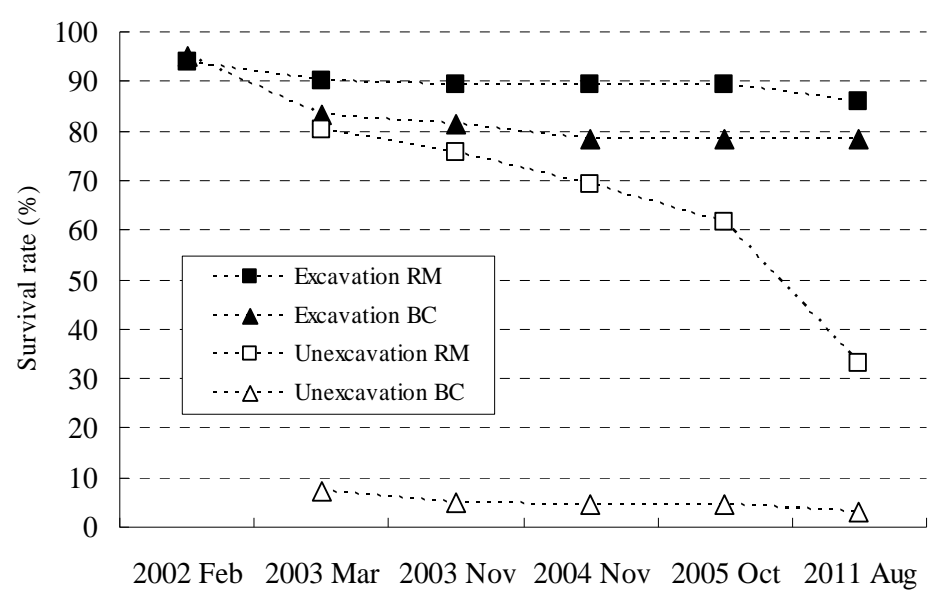


Figure 7. The mean tree height from 5 months to 10 years after planting. RM-Rhizophora mucronata, BC—Bruguiera cylindrica.

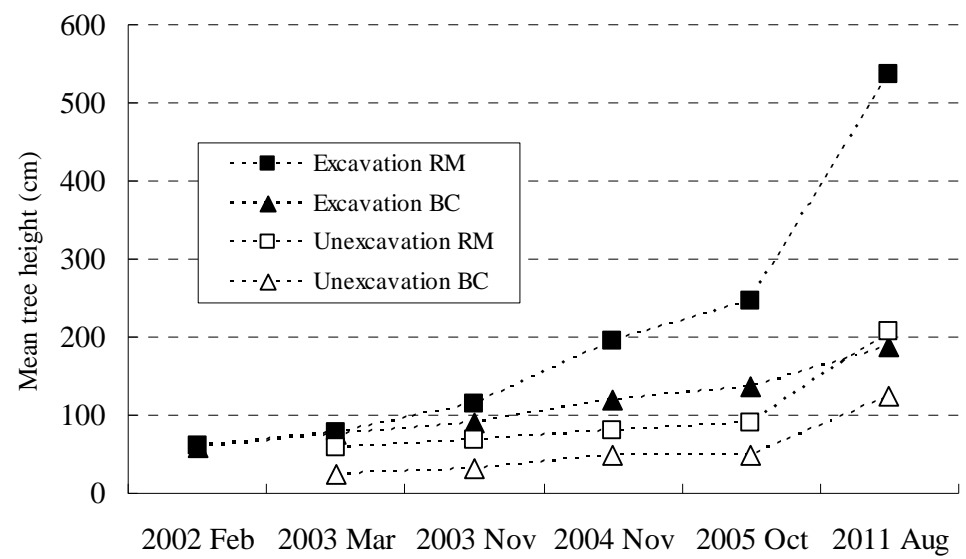

\subsection{Increment of Standing Biomass}

In accordance with different survival and growth rates, biomass accumulation differed markedly between the unexcavated and excavated area and between the RM and BC species (Table 2). Highest biomass was recorded for RM in the excavated area with 98.7 ton/ha, and the lowest value was for BC in the unexcavated area with 0.53 ton/ha. A decrease of the standing biomass in RM over time is due to its decreased survival rate and low growth rate.

Table 2. Estimation of the standing biomass (ton/ha).

\begin{tabular}{cccc}
\hline \multirow{2}{*}{ Treatment } & \multirow{2}{*}{ Spp. } & \multicolumn{2}{c}{ Timeline } \\
\cline { 3 - 4 } & & 2005 October & 2011 August \\
\hline \multirow{2}{*}{ Excavated area } & $\mathrm{RM}$ & 19.9 & 98.7 \\
& $\mathrm{BC}$ & 13.0 & 28.8 \\
\hline \multirow{2}{*}{ Unexcavated area } & $\mathrm{RM}$ & 1.48 & 1.04 \\
& $\mathrm{BC}$ & 0.07 & 0.53 \\
& $\mathrm{AM}$ & 16.6 & 16.9 \\
\hline
\end{tabular}

Note: RM-Rhizophora mucronata; BC—Bruguiera cylindrical; AM-Avicennia marina.

A higher standing biomass, in the 6 years from October 2005 to August 2011, was recorded in the excavated area. The species RM and BC accumulated 5 times and 2.2 times more standing biomass in the excavated area than in the unexcavated area, respectively.

Aerial images of the study site were taken from a radio-controlled helicopter on two different occasions in September 2003 and February 2006 (Figure 8). Comparison of the two images explicitly demonstrated the opposite growth behavior in two different areas, e.g., vigorous growth in the excavated area but poor growth in the unexcavated area. The growth rate of AM, which colonized into the unexcavated area, was rather high in the first two years. However, numbers of AM trees and growing areas of AM were almost the same in September 2003 and February 2006. Moreover, the standing biomass of AM remained similar between October 2005 and August 2011 (Table 2). These facts indicate that the fast growing species AM can capture carbon quickly but can only continue its ability for a short period. 
Without land treatment, the abandoned area will remain as unproductive land for a long time being dominated by AM and halophyte. To facilitate improved forest recovery of an abandoned shrimp pond and to enhance forest productivity, hydraulic restoration is inevitable.

Figure 8. Aerial pictures were taken from a radio-controlled helicopter from $500 \mathrm{~m}$ above sea level (a) in September 2003 and (b) in February 2006. The area enclosed by the red line shows the excavated area. Comparison of the two images indicates that favorable mangrove growth was seen in the excavated area and that growth of AM was negligible in the unexcavated area despite its vigorous initial growth.

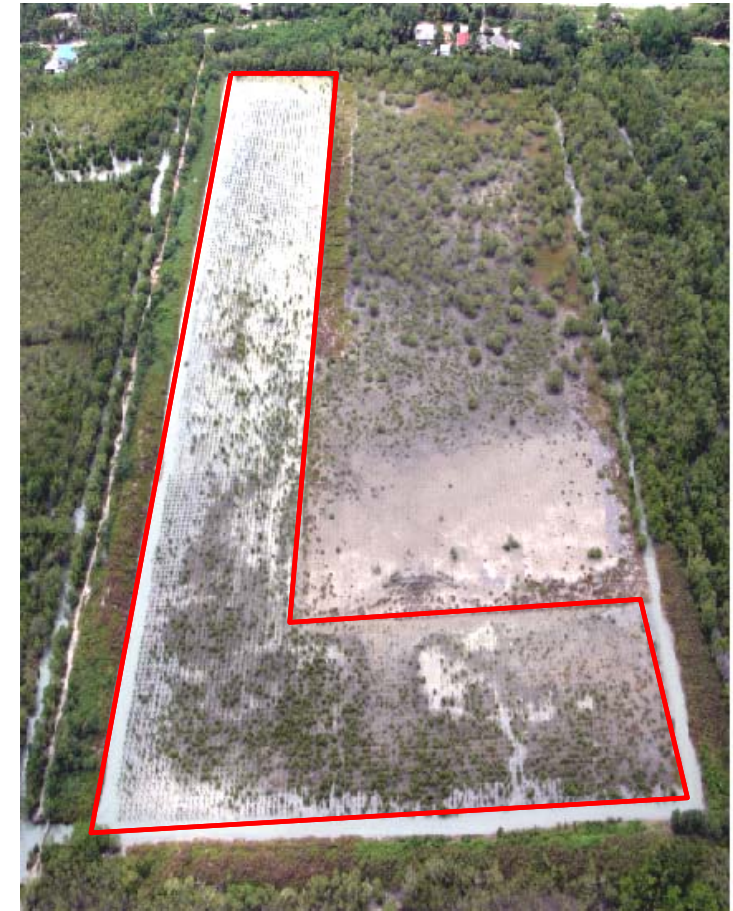

(a)

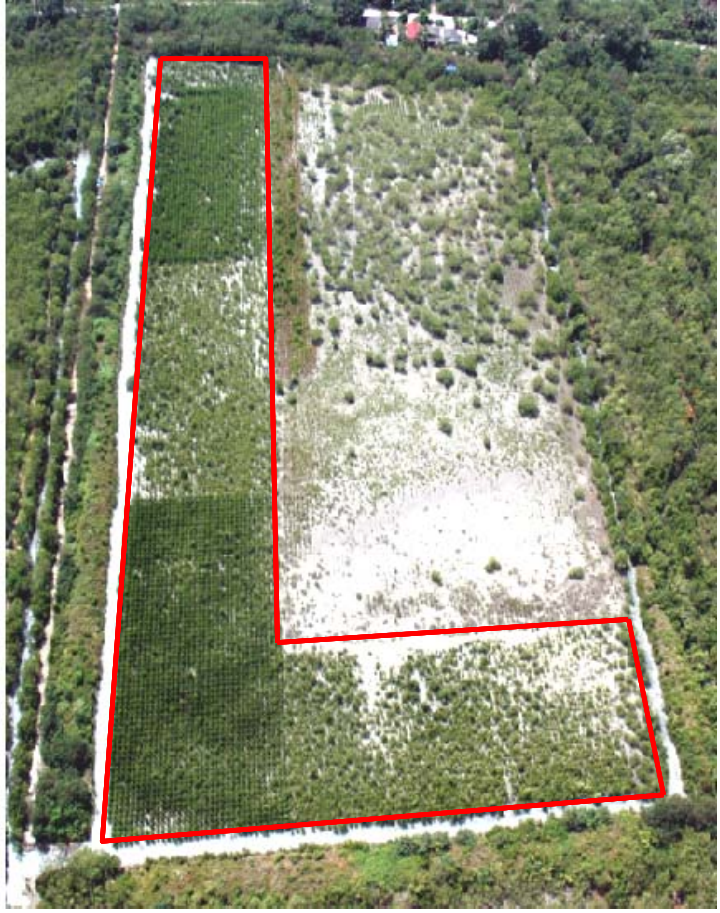

(b)

\subsection{Content of Soil Organic Carbon}

Similar amounts of total $\mathrm{C}$ were recorded for the unexcavated and excavated areas when measured in July 2003, but these figures increased by contrasting amounts when measured in September 2005 and they differed greatly in August 2011 (Figure 9). The excavated area showed higher total C contents than the unexcavated area, which may reflect the contrasting rates of tree growth in the two areas. Moreover, carbon from external sources can be imported through inflow and trapped in sediment in the excavated area. The unexcavated area also recorded a slight increase in total C. This would be caused by biomass accumulation of AM which intruded and grew quickly for a short period.

Prior to the land excavation (August 2001), the surface soil to a depth of $5 \mathrm{~cm}$ contained $71.8 \mathrm{tC} / \mathrm{ha}$ of soil OC (Figure 10). This amount is low compared with those of natural mangrove forests which represented 370-553 tC/ha [27]. Significant amounts of soil OC may have been lost during the construction of shrimp ponds or after abandonment of the pond in this area. $\mathrm{C}$ stocks that were once resistant to decay (under anaerobic conditions) can be lost through aerobic respiration [28]. Clearing of mangrove forests results in statistically significant reductions of C stocks in sediments [29]. Up to 50\% 
of soil C was lost over an 8-year period [30,31] and this study estimated $13 \%-20 \%$ loss in nearly 20 years from the 1980s to 2001.

Figure 9. Total C \% from August 2001 to August 2011. Bars in July 2003, September 2005 and August 2011 denote the means and standard deviations of 10-12 replicates.

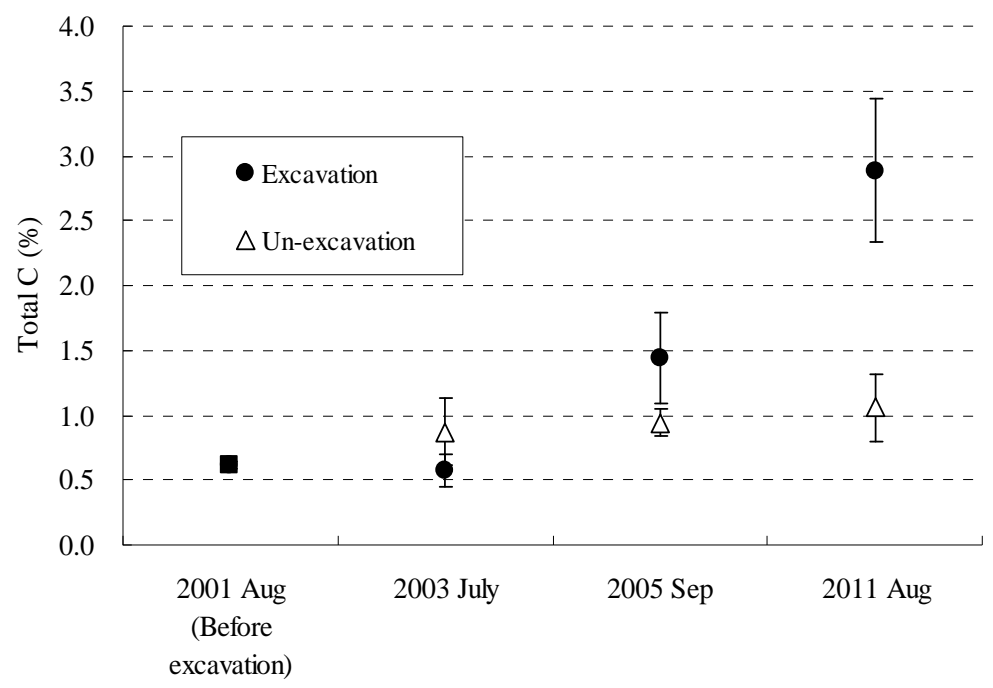

Figure 10. Soil organic carbon content (tC/ha) in $5 \mathrm{~cm}$ soil depths at three different times as indicated. Bars denote the means and standard deviations of 9-10 replicates. Data with different letters are significantly different (Tukey’s HSD test, $p<0.05$ ).

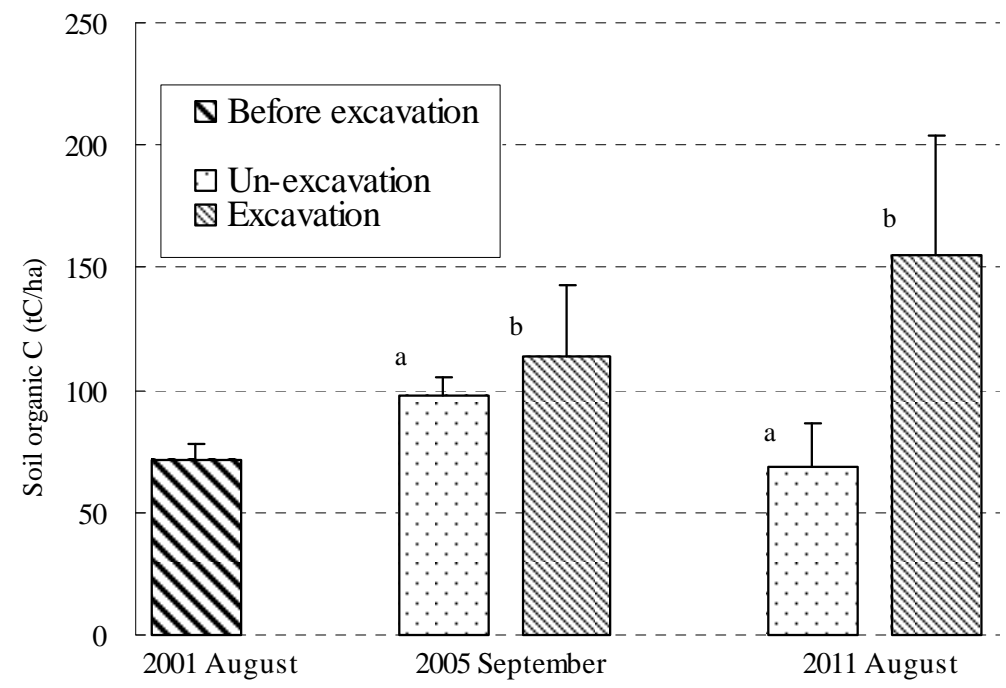

Soil OC increased from 113.3 tC/ha (September 2005) to 154 tC/ha (August 2011) in the excavated area while in the unexcavated area soil OC decreased from 97.4 tC/ha (September 2005) to 68.3 tC/ha (August 2011) in 6 years (Figure 10). While AM grew vigorously from September 2001 for some years, soil OC could also increase so that soil OC in September 2005 was higher than in August 2001. However, soon after AM growth slowed down, a degree of soil OC decomposition intensified resulting in lower soil OC content measured in August 2011. Unless hydraulic conditions are improved in the unexcavated area, soil OC decomposition is likely to be continuing. 
Cohen et al. [30] reported that an increase in tidal height of $20 \mathrm{~cm}$ at the mangrove stand corresponds to a twofold increase in inundation frequency. In this study it was revealed that excavating $25 \mathrm{~cm}$ increased the annual inundation time from 463 hours to 7,597 hours (Figure 5). With this improvement of hydraulic conditions, soil OC accumulation rate is likely to have increased drastically. We adopted one uniform depth for excavation in this study. Our study examining effects of excavation on mangrove growths was therefore limited by a lack of growth data at other excavation depths. Before a certain mangrove species is planted, adequate inundation frequency shall be determined. Since optimum inundation frequency is different among mangrove species, a depth to be excavated has to be sought for species by species.

The unexcavated area has no inundation for 4 months (April, August, September, October) (Figure 5). Severe dry conditions without inundation may accelerate soil OC decomposition, which is the main reason for carbon loss during the 6 year period from September 2005 to August 2011 in the unexcavated area.

IPCC deals with carbon changes in the chapter of Land-use change and forestry (LULUCF), however its consideration is mainly given to land conversions from inland forest and/or grassland. Since mangrove ecosystems contain a huge amount of carbon underground [31], land use change in a mangrove ecosystem should be paid more attention since a significant amount of carbon will be lost due to the change from mangrove to shrimp pond at many coastal areas in the tropics.

The REDD+ program for the valuation of carbon stored forests includes conservation, enhancement of carbon stocks, and the sustainable management of forests. Mangroves are eligible for the REDD+ program. However, large uncertainties still exist in the carbon sequestration potential of mangroves [32]. Hydraulic conditions significantly determine mangrove forest development and the rate of carbon sequestration as well. Therefore, appropriate hydraulic conditions have to be implemented for enhancement of mangrove carbon stocks. Hydrology restoration should be completed, especially if mangrove rehabilitation is intended to sequester atmospheric $\mathrm{CO}_{2}$.

\section{Conclusions}

Excavation as a tool for land treatment led to an increase in the biomass accumulation of planted mangroves. In the excavated area of the study site, planted RM accumulated 98.7 ton/ha of biomass in 10 years, while BC accumulated 28.8 ton/ha. In contrast, biomass accumulation in the unexcavated area was rather low: 1.04 ton/ha for RM and 0.53 ton/ha for BC. Moreover, soil C accumulation doubled in the excavated area while it decreased in the unexcavated area that suffered from oxidic decomposition. Carbon recovery can be explained by the increased frequency of tidal flooding as a consequence of excavation. Effects of hydraulic restoration in blue carbon sinks are rather significant and should be implemented-especially as mangrove plantations are considered to reduce atmospheric concentrations of $\mathrm{CO}_{2}$.

\section{Acknowledgments}

The research was undertaken as part of a Joint Research Project participated by the Department of Marine and Coastal Resources (DMCR), Thailand, Kansai Electric Power Co., Inc., Japan, and Kanso 
Technos Co., Ltd., Japan, from 1998 to 2007. We would also like to thank the staff of Mangrove Resources Research \& Development Station Nr.6, DMCR, for their collaborative work in the field.

\section{Conflict of Interest}

The authors declare no conflict of interest.

\section{References}

1. Mcleod, E.; Chmura, G.L.; Bouillon, S.; Salm, R.; Bjork, M.; Duarte, C.M.; Lovelock, C.E.; Schlesinger, W.H.; Silliman, B.R. A blueprint for blue carbon: Toward an improved understanding of the role of vegetated coastal habitats in sequestering $\mathrm{CO}_{2}$. Front. Ecol. Environ. 2011, 9, 552-560.

2. Nellemann, C.; Corcoran, E.; Duarte, C.M.; Valdes, M.; de Young, L.; Fonseca, L.; Grimsditch, G. Blue Carbon: The Role of Healthy Oceans in Binding Carbon-A Rapid Response Assessment; GRID-Arendal (United Nations Environment Programme): Arendal, Norway, 2009.

3. Chmura, G.L.; Anisfeld, S.C.; Cahoon, D.R.; Lynch, J.C. Global carbon sequestration in tidal, saline wetland soils. Glob. Biogeochem. Cycles 2003, 17, 1111-1123.

4. Duarte, C.M.; Middelburg, J.; Caraco N. Major role of marine vegetation on the oceanic carbon cycle. Biogeosciences 2005, 2, 1-8.

5. Bouillon, S.; Borges, A.V.; Castañeda-Moya, E.; Diele, K.; Dittmar, T.; Duke, N.C.; Kristensen, E.; Lee, S.Y.; Marchand, C.; Middelburg J.J.; Rivera-Monroy, V.H.; Smith, T.J., III; Twilley, R.R. Mangrove production and carbon sinks: A revision of global budget estimates. Glob. Biogeochem. Cycles 2008, 22, GB2013:1-GB2013:12.

6. Duarte, C.M.; Marbà, N.; Gacia E.; Fourqurean, J.W.; Beggins, J.; Barrón, C.; Apostolaki, E.T. Seagrass community metabolism: Assessing the carbon sink capacity of seagrass meadows. Glob. Biogeochem. Cycles 2010, 24, GB4032:1-GB4032:8.

7. Kennedy, H.; Beggins, J.; Duarte, C.M.; Fourqurean, J.W.; Holmer, M.; Marba, N.; Middelburg, J.J. Seagrass sediments as a global carbon sink: Isotopic constraints. Glob. Biogeochem. Cycles 2010, 24, GB4026:1-GB4026:8.

8. United Nations Framework on Climate Change. Land-Use Change and Forestry (LULUCF) Home Page. Available online: http://unfccc.int/methods_and_science/lulucf/items/3060.php (accessed on 12 June 2012).

9. Valiela, I.; Bowen, J.L.; York, J.K. Mangrove forests: One of the world's threatened major tropical environments. BioScience 2001, 51, 807-815.

10. Alongi, D.M. Present state and future of the world's mangrove forests. Environ. Conserv. 2002, 29, 331-349.

11. Bridgham, S.D.; Megonigal, J.P.; Keller, J.K.; Bliss, N.B.; Trettin, C. The carbon balance of North American wetlands. Wetlands. 2006, 26, 889-916.

12. FAO (Food and Agricultural Organization). The world's Mangroves 1980-2005; FAO: Rome, Italy, 2007.

13. Duarte, C.M.; Dennison, W.C.; Orth, R.J.W.; Carruthers, T.J.B. The charisma of coastal ecosystems: Addressing the imbalance. Estuaries Coast 2008, 31, 233-238. 
14. Granek, E.F.; Ruttenberg, B.I. Changes in biotic and abiotic processes following mangrove clearing. Estuar. Coast. Shelf Sci. 2008, 80, 555-562.

15. Sweetman, A.K.; Middelburg, J.J.; Berle, A.M.; Bernardino, A.F.; Schander, C.; Demopoulos, A.W.J.; Smithal, C.R. Impacts of exotic mangrove forests and mangrove deforestation on carbon remineralization and ecosystem functioning in marine sediments. Biogeosciences 2010, 7, 2129-2145.

16. Charuppat, T.; Charuppat, J. Application of Landsat-5 (TM) for monitoring the changes of mangrove forest area in Thailand (in Thai). In Proceedings of the 10th National Seminar on Mangrove Ecology, Songkhla, Thailand, 25-28 August 1997; pp. 1-5.

17. Sathirathai, S.; Barber, E.B. Valuing mangrove conservation in Southern Thailand. Contemp. Econ. Policy. 2001, 19, 109-122.

18. Lewis, R.R. Ecologically based goal setting in mangrove forest and tidal marsh restoration. Ecol. Eng. 2000, 15, 191-198.

19. Lewis, R.R. Ecologically engineering for successful management and restoration of mangrove forests. Ecol. Eng. 2005, 24, 403-418.

20. Turner, R.E.; Lewis, R.R. Hydrologic restoration of coastal wetlands. Wetl. Ecol. Manag. 1997, 4, 65-72.

21. Brockmeyer, R.E.; Rey, J.R.; Virnstein, R.W.; Gilmore, R.G.; Earnest, L. Rehabilitation of impounded estuarine wetlands by hydrologic reconnection to the Indian River Lagoon, Florida (USA). Wetl. Ecol. Manag. 1997, 4, 93-109.

22. Matsui, N.; Suekuni, J.; Nogami, M.; Havanond, S.; Salikul, P. Mangrove rehabilitation dynamics and soil organic carbon changes as a result of full hydraulic restoration and re-grading of a previously intensively managed shrimp pond. Wetl. Ecol Manag. 2010, 18, 233-242.

23. Chusrinuan, N.; Tanavud, C.; Yongchalermchai, C. Impacts of shoreline erosion on coastal ecosystems in Songkhla Province. Songklanakarin J. Sci. Technol. 2009, 31, 237-245.

24. Yamamura, K. Key-factor/key-stage analysis for life table data. Ecology 1999, 80, 533-537.

25. Meepol, W. Growth and litter production of 7-10 years old Rhizophora mucronata Lamk. Planted on abandoned shrimp farm at Donsak, Surat Thani Province (in Thai). J. For. Manag. 2009, 3, 35-55.

26. Pranchai, A. Mangrove Rehabilitation on Abandoned Shrimp Ponds at Amphoe Khanom, Changwat Nakorn Sri Thammarat. M.S. Thesis, Kaset Sart University: ChatuChak Bangkok, Thailand, 2003.

27. Matsui, N.; Yamatani, Y. Estimated total stocks of sediment carbon in relation to stratigraphy underlying the mangrove forests of Sawi Bay. Phuket Mar. Biol. Cent. Spec. Publ. 2000, 22, 15-25.

28. Couwenberg, J.; Dommain, R.; Joosten, H. Greenhouse gas fluxes from tropical peatlands in south-east Asia. Glob. Chang. Biol. 2010, 16, 1715-1732.

29. Lovelock, C.E.; Ruess, R.W.; Feller, I.C. $\mathrm{CO}_{2}$ efflux from cleared mangrove peat. PLoS One 2011, 6, e21279:1-e21279:4.

30. Cohen, M.C.L.; Lara, R.J.; Szlafsztein, C.; Dittmar, T. Mangrove inundation and nutrient dynamics from a GIS perspective. Wetl. Ecol. Manag. 2004, 12, 81-86.

31. Matsui, N. Estimated stocks of organic carbon in mangrove roots and sediments in Hinchinbrook Channel, Australia. Mangrove and Salt Marshes. 1998, 2, 199-204. 
32. Alongi, D.M. Carbon payments for mangrove conservation: Ecosystem constraints and uncertainties of sequestration potential. Environ. Sci. Policy 2011, 14, 462-470.

(C) 2012 by the authors; licensee MDPI, Basel, Switzerland. This article is an open access article distributed under the terms and conditions of the Creative Commons Attribution license (http://creativecommons.org/licenses/by/3.0/). 